\title{
EUCARISTIA EM TEMPOS DE PANDEMIA
}

\author{
Considerações de um pastor
}

\author{
Dr. Dom Hernaldo Pinto Farias ${ }^{\star}$ \\ DOI: https://doi.org/10.52451/teopraxis.v37i129.8 \\ Recebido: 10 de dezembro de 2018 | Aprovado: 02 de abril de 2019
}

Resumo: O presente artigo quer aprofundar as celebrações litúrgicas, mais precisamente as celebrações eucarísticas, e fazer algumas provocações a partir de práticas realizadas neste tempo de pandemia, nem sempre condizentes com aquilo que a Igreja orienta. Ao mesmo tempo quer lançar luzes sobre o contexto que estamos vivendo a partir do Sacramento da Eucaristia.

Palavras-chave: Eucaristia. Missa. Liturgia das Horas. Igreja. Oportunidade.

\section{Introdução}

A pandemia da Covid-19 pegou todo o mundo de surpresa, atingindo não apenas os sistemas de saúde municipais, a economia das nações, mas também a vida da Igreja e, em particular, sua liturgia. Não tem sido fácil compreender e acolher toda essa realidade. E mais: para nós, não é possível acolhê-la sem a profunda vivência da fé no Cristo morto e ressuscitado. Durante esses meses que já se passaram, para muitos presbíteros alimentar a fé pessoal e também a fé da porção do rebanho a ele confiado e, por consequência, orientar a vida celebrativa de ambos tem sido um grande desafio.

O presente artigo foi solicitado pelo Superior Geral da Congregação do Santíssimo Sacramento, Padre Eugênio Barbosa Martins, SSS, para que os especialistas das mais diversas

^ Bispo da Diocese de Bonfim (BA). Possui Mestrado em Teologia Dogmática pela PUC/SP; Mestrado e Doutorado em Sagrada Liturgia pelo Pontifício Ateneu Santo Anselmo de Roma/IT. Foi assessor da Comissão Episcopal para a Liturgia da CNBB e Membro do Centro de Liturgia Dom Clemente Isnard. Email: hepifari@gmail.com 
áreas do saber pudessem lançar luzes sobre essa realidade a partir da Eucaristia, como expressão do carisma eymardiano ${ }^{1}$, pois, segundo a Regra de Vida da Congregação, "Procuramos compreender toda a realidade humana à luz da Eucaristia, 'ápice e fonte' da Igreja" ( $\left.\mathrm{n}^{\circ} 34\right)$.

Impedidos de celebrar principalmente a Eucaristia com a presença indispensável dos fiéis - discussão que deve ser feita em outro momento -, muitos clérigos têm recorrido aos atuais meios de comunicação com transmissões de celebrações on-line, além daquelas já transmitidas pelas redes de televisão. A princípio, não isso é ruim, pois a Igreja, desde o Concílio Vaticano II, tem-se preocupado com a comunicação social, chegando a publicar diretórios para tal fim, aprovados em diversas Conferências Episcopais ${ }^{2}$. A questão é que, além de, na maioria das vezes, tais transmissões não primarem pela discrição e decoro, perfeição e eficácia (SC 20; IM 14), por causa das improvisações e amadorismos, elas têm veiculado teologias e formas litúrgicas personalistas, revelando vícios que antes eram mantidos no recôndito de suas paróquias e, o mais preocupante, escancarando ao mundo a baixa preparação teológica e litúrgica de muitos. Num mundo globalizado, a Igreja globalizou também suas fraquezas litúrgicas.

Limitamo-nos a citar apenas algumas dessas transmissões, para não nos alongarmos e para adentrarmos no conteúdo que nos propusemos partilhar.

\section{Eucaristia manipulada}

No domingo de Ramos da Paixão do Senhor, um presbítero, após um breve canto, começou a Eucaristia persignando-se e dizendo: "Em nome do Pai, do Filho, da Mãe e do Espírito Santo". Essa "fórmula" ritual, além de ser bizarra pela falta da

1 São Pedro Julião Eymard, fundador da Congregação do Santíssimo Sacramento.

2 Cf. CNBB. Diretório de comunicação da Igreja no Brasil (Documentos da CNBB 99). Brasília: Ed. CNBB, 2014. 
necessária conjunção e o acréscimo de uma quarta pessoa (?) da Santíssima Trindade, nos leva a questionar o antiquíssimo axioma lex orandi - lex credendi (Próspero de Aquitânia - † após 455), pois Deus uno e trino, fonte e princípio de toda a fé professada pela Igreja em sua liturgia, que é a theologia prima, deixa de ser experimentado pela comunidade celebrativa como obra de salvação querida pelo Pai, operada por Cristo e continuada na liturgia, pela condução do Espírito Santo (SC 5-6). Transmitir conteúdos contrários à liturgia da Igreja é levar as pessoas a uma errônea e distorcida experiência da fé, submetendo-a a conceitos pessoais daqueles que deveriam ser guardiões e mestres da mesma (SC 14), pois a norma do orar determina a norma do crer. Fé que é eclesial e não subjetivista, e o presbítero presidente da celebração “deve estar lembrado de que ele é servidor da sagrada Liturgia e de que não lhe é permitido, por própria conta, acrescentar, tirar ou mesmo mudar qualquer coisa na celebração da Missa" (IGMR 24).

No mesmo domingo de Ramos, um bispo, além de outros presbíteros que também utilizaram a "grande ideia", fixou nos bancos da igreja fotos impressas de fiéis de sua diocese. Para completar essa estranha cena, o prelado entrou com um presbítero assistente, nave adentro, munido de báculo, como pastor de seu rebanho de papel. A participação ativa, consciente e frutuosa dos fiéis por sua presença atuante na liturgia não é uma "brincadeira de papel", como canta certa música brasileira sobre Papai Noel. Ela é a expressão da força do Espírito que age na ritualidade da Igreja, precisamente, através de seus ritos e preces (SC 48), o que também nos levaria a questionar o conceito e a orientação de "participação espiritual", quando se fala de liturgia hoje. Além do mais, o báculo pastoral é uma das insígnias daquele que fora constituído pastor de seu rebanho reunido em torno ao presbitério e não, fictício. É o sinal de seu múnus pastoral, a exemplo do Cristo, Bom Pastor e, por isso mesmo, deve ser usado, sobretudo, em seu próprio território ${ }^{3}$.

3 Cf. CNBB, Cerimonial dos Bispos (Cerimonial da Igreja), n.59. 
Durante a Missa Vespertina da Ceia do Senhor, as “criatividades selvagens" foram até maiores: o lava-pés, já orientado pela Santa Sé para que fosse omitido (cf. Decreto Em tempo de Covid-19 II), foi "feito" por presbíteros que lavaram desenhos de pés, outro que lavou os pés das imagens dos santos de sua igreja, ou outro ainda, que lavou os pés de bonecos, somente para citar alguns exemplos. Ora, o chamado "lava-pés", que já é um rito opcional nesta celebração de abertura do grande Tríduo Pascal para nossa participação nos mistérios do Senhor, não é uma mera encenação. Por ele, ritualizamos evocando a força teológica do serviço maior prestado por Cristo ao entregar sua vida ao mundo, porque muito amou. Teologia joanina muito cara à Igreja. Este gesto ritual é, portanto, a expressão de um amor incondicional que, celebrado na e pela Eucaristia da Igreja, deve ser imitado por todos aqueles que professam a fé em Jesus Cristo, a tal ponto de tornar-se a marca-opção de vida de seus discípulos e discípulas (cf. Jo 13,14.35).

Padres adotaram a prática de, após sua Missa, distribuir a comunhão eucarística a fiéis que fazem filas à porta das igrejas, mesmo que, segundo os "pastores", estejam tomando os cuidados higiênicos e sanitários exigidos pelas autoridades. Houve também a prática do Drive-through ou, popularmente, drive-thru - através do carro. Este é um método usado no mundo do consumismo capitalista para vender produtos a clientes que, confortavelmente, os adquirem sem sair de seus veículos. A comunhão eucarística tem sido tratada quase como um verdadeiro fast-food (comida rápida), fabricada e preparada para não fazer o cliente esperar, e para recebê-la no conforto de seus carros por causa da frenética correria da vida, mas agora também por causa do "cuidado" com a possibilidade de contágio do novo coronavírus. Aqui, não só a ritualidade da Igreja é vilipendiada, mas, sobretudo, a Eucaristia é destituída de sua força de Ceia do Senhor, como alimento da vida eterna. 
Não questionamos o fato da distribuição da sagrada comunhão em si, porque a Igreja normatiza tal prática ${ }^{4}$, mas a forma e o objetivo com que está sendo distribuída: como se comungar fosse o antídoto para a proteção viral ou porque o que importa ao fiel é somente a comunhão eucarística, sem qualquer ritualidade ou disposição interior de participação no Mistério do Senhor em sua íntima relação com a Celebração Eucarística (Cf. SCCEFM 13-15 e 25). E o clero se vê na obrigação de atender aos distorcidos desejos de grupos ou indivíduos.

E o que dizer de quando a Eucaristia é trasladada em um carro (quase alegórico, próprio dos carnavais), como se fosse um objeto para afastar o vírus das portas daqueles que a ela se voltam, devotamente? Sem falar nos desfiles de paramentos medievais de gostos duvidosos. A exposição da Eucaristia foi finalmente regulada pelo Ritual promulgado em 1973 e exige cuidados por parte dos pastores que, às vezes, a fazem tão somente para dar a bênção, o que tem acontecido com frequência nesses dias. Não é demasiado recordar que, desde 1967, com a Instrução Eucharisticum Mysterium, n ${ }^{\circ}$ 66, a Igreja proibiu a exposição da Santíssima Eucaristia "unicamente para dar a bênção" (SCCEFM 89). Trata-se de sabedoria e prudência da Igreja para não facilitar as manipulações e, quem sabe, magias no trato com a Eucaristia.

E assim, tantas outras práticas nos têm preocupado e provocado muitas reflexões e questionamentos. Fiquemos, porém, apenas com as citadas acima.

4 Cf. SAGRADA CONGRAGAÇÃO PARA O CULTO DIVINO, A sagrada comunhão e o culto do mistério eucarístico fora da missa, n.16. De agora em diante citado como SCCEFM. 


\section{Perdemos oportunidade única?}

Desde o início desta pandemia, aqui no Brasil com o primeiro caso divulgado no dia 26 de fevereiro do corrente ano, pesquisadores de várias áreas do saber humano e também teólogos, entre eles liturgistas, têm feito reflexões com o objetivo de iluminar essa realidade, que já se apresentava de forma quase anacrônica. Entre as várias reflexões houve uma que nos chamou a atenção: este é o momento propício para repensarmos e revalorizarmos a liturgia da Igreja doméstica. Não faltaram sugestões como a recuperação da prática da bênção dos alimentos, perdida nos últimos tempos; a oração antes de dormir, com a importante bênção dos pais a seus filhos; a leitura orante da Bíblia, como forma de deixar-se orientar pela Palavra de Deus, entre outras.

Uma forma orante de alimentar a fé nos parece mais apropriada para esta reflexão: a prática da Liturgia das Horas (LH) na Igreja doméstica e na vida dos presbíteros ou religiosos.

A Igreja tem sua forma de oração, prioritariamente comunitária $^{5}$, que é a Liturgia das Horas, abandonada por muitos, sobretudo por leigos e leigas que, apesar da recuperação aos mesmos pelo Concílio (SC 100), não foram iniciados nos mistérios e, por isso, buscam às apalpadelas se manterem de pé às custas de práticas devocionistas. Será que não perdemos a oportunidade dessa recuperação na vida da Igreja, nestes tempos de pandemia? Em vez de transmitir práticas litúrgicas duvidosas, no intuito de manter a vida orante dos fiéis, ou de manipular a Eucaristia de diversas formas, como se fosse a única forma celebrativa da Igreja, apesar de ser a mais sublime, não seria o caso de incentivarmos os leigos a que alimentem sua fé através da oração da Liturgia das Horas? Os próprios presbíteros, não

5 Cf. Instrução Geral sobre a Liturgia das Horas, In. As introduções gerais dos livros litúrgicos, São Paulo: Paulus, 2003, n.9, p.288. De agora em diante citado como IGLH. 
perdemos nós a oportunidade de reavivar nosso compromisso sacramental de rezar as horas do Senhor? Não seria também uma forma de solidariedade do clero com os milhares de leigos e leigas que, raramente, podem participar de uma Celebração Eucarística (como em tantos lugares do Brasil, onde comunidades passam um ou mais meses sem este Sacramento central da vida da Igreja), na certeza eclesial de que também nos unimos aos mistérios do Cristo quando celebramos a LH, meditando e cantando a Palavra de Deus?

Quem sabe o excesso de zelo pastoral nos tenha impedido de experimentar a simplicidade de nossa vida celebrativa, como se a Liturgia das Horas fosse "apenas" uma oração e, como fuga, fomos buscar o "espetáculo eucarístico", quase transformando a Eucaristia em simples objeto devocional.

\section{Liturgia das Horas - forma privilegiada de participação no mistério eucarístico}

Ao rezar a LH, a Igreja santifica "o dia e toda a atividade humana” (IGLH 11), pois esta oração é "fonte de piedade e da multiforme graça divina e [serve] também de alimento à oração pessoal" (IGLH 19). Por isso mesmo, a LH é "cume e fonte da atividade pastoral" (IGLH 18), recomendada pela Igreja para que os pastores, por meio dela, "encontrem [não só] uma fonte de piedade e alimento de sua oração pessoal, mas [também] nutram e incentivem, através de intensa contemplação, sua atividade pastoral e missionária para proveito de toda a Igreja de Deus" (IGLH 28).

Santificar a hora, o dia, as atividades, significa que pela Liturgia das Horas a Igreja revela sua genuína natureza de participante dos mistérios de Cristo pela oração (Cf. IGLH 22) a cada hora do dia, durante a semana e em cada tempo do ano litúrgico.

Aquele que faz uso da LH, portanto, experimenta os mistérios de Cristo a cada hora, pascalizando, assim, sua vida e 
todas suas atividades. Tudo é lido, interpretado e vivido a partir da força da Páscoa de Cristo, que revitaliza os membros de seu Corpo, a Igreja. Das trevas à luz, da noite ao dia, da morte à vida. Noite e dia são transformados em experiência pascal cotidiana porque o Cristo mesmo, presente na ação orante salmódica da Igreja (SC 7), canta ao Pai seus mistérios (Cf. IGLH 13), tornando-a participante dos mesmos.

Limitando-nos apenas às horas do dia, tomando como referência a primeira semana, com as Vésperas, canta-se o mistério da morte do Cristo que salmodia a tentativa de domínio das trevas sobre o mundo, sobre ele. Este canto, porém, é pleno de confiança na bondade, misericórdia e ação de um Deus que não abandonou seu Filho na região dos mortos, e a morte não teve sua vitória. E Cristo canta: "O Senhor é minha luz e salvação; de quem eu terei medo? O Senhor é a proteção de minha vida; perante quem eu temerei?" (S1 26 - quarta-feira). É por isso mesmo que a Esposa glorifica aquele que é sua "Cabeça..., o princípio, o Primogênito entre os mortos" (Cl 1,18 - quarta-feira) e suplica a Deus pelos irmãos e irmãs falecidos, para quem espera a vida eterna. No novo dia que surge, com as Laudes, a esperança da vitória do Cristo sobre o pecado, as trevas e sobre a morte se faz realidade, quando se canta a ressurreição: "Vós sois grande, Senhor, para sempre... Porque vós castigais e salvais, fazeis descer aos abismos da terra e de lá nos trazeis novamente" (Ct. Tb 13,2 - terça-feira). Nas Horas Médias, proclamando os mistérios de seus sofrimentos e crucifixão, o justo lamenta o abandono e, confiante em Deus, canta: "Até quando, ó Senhor, me esquecereis? Até quando escondereis vossa face? Até quando estará triste minha alma? e o coração angustiado cada dia? Até quando o inimigo se erguerá?" (Sl 12,2-3 - terça-feira). Sem citar o Ofício dos fiéis defuntos, com o qual a Igreja canta o mistério da morte de Cristo na morte dos irmãos e irmãs, reafirma que não é a tristeza e o choro que devem prevalecer, mas a esperança 
naquele que é o vencedor da morte, pois ele há de conduzir a sua companhia todos os que morreram na fé, em seu Filho Jesus Cristo.

Ora, nestes angustiantes dias de pandemia, quando a dor e a morte buscam seu domínio, quando o desespero parece querer ser a voz mais forte, quando o mundo não suporta mais as infindáveis trevas, ressoam os salmos da Igreja que canta com seu Senhor: "Guardei minha fé, mesmo dizendo: 'É demais o sofrimento em minha vida!' Confiei, quando dizia na aflição: 'Todo homem é mentiroso! Todo homem"' (Sl 115,10-11 Comum dos Apóstolos, São Matias). Pela oração, a Igreja pascaliza a vida, interpretando-a à luz dos mistérios de Cristo que vive e age nela. Ela, dessa forma, como mãe, se solidariza com toda a humanidade e, no sofrimento de seus filhos e filhas, continua a acreditar na força da vida que venceu a morte.

Tudo isso nos remete à Eucaristia, sacramento por excelência da celebração e participação da Igreja nos mistérios da Páscoa de Cristo. A Liturgia das Horas, por sua vez, está tão intimamente ligada à Celebração Eucarística que "alarga aos diferentes momentos do dia o louvor e a ação de graças, a memória dos mistérios da salvação, as súplicas, o antegozo da glória celeste, contidos no mistério eucarístico...” (IGLH 12). Por essa unidade com a Eucaristia, torna-se para a Igreja seu "sacrifício vespertino" (Sl 140,2), evocando o próprio sacrifício do Senhor quando, no cenáculo, confiou os santos mistérios a seus apóstolos e o realizou logo depois, na cruz (Cf. IGLH 39). Esta é a forma com a qual se pode falar de "sacrifício espiritual", participação espiritual ou "sacrifício de louvor": como fruto dos lábios que glorificam o nome do Senhor (Cf. Hb 13,15; IGLH 15).

Mais ainda: para a Igreja, "a própria celebração eucarística tem na Liturgia das Horas sua melhor preparação, porque esta suscita e nutre da melhor maneira as disposições necessárias para uma frutuosa celebração da Eucaristia, quais são a fé, a esperança, a caridade, a devoção, o espírito de sacrifício" (IGLH 12). 
A LH encontra tamanha importância por parte da Igreja que, por causa dos mistérios do Cristo que são estendidos no decurso do dia e do tempo, uma das horas pode ser usada como rito para o culto eucarístico fora da Missa (exposição da Santíssima Eucaristia), sobretudo uma das horas principais (Laudes ou Vésperas). "Na verdade, por ela os louvores e as ações de graças tributados a Deus na celebração da Eucaristia estendem-se às diversas horas do dia e as preces da Igreja se dirigem a Cristo e por Cristo ao Pai em nome de toda a humanidade" (SCCEFM 96). De fato, pela adoração a Igreja prolonga a Eucaristia celebrada, contemplando no Pão Eucaristizado os mistérios daquele que nos deu a salvação.

A Liturgia das Horas é, de fato, uma forma privilegiada de participação nos mistérios eucarísticos da Igreja e pode ser incentivada e melhor experimentada por todos, em particular pelas famílias nesses difíceis tempos de isolamento social que vive a humanidade.

\section{À guisa de conclusão}

É curioso, e quase paradoxal, que a forma de compreender a realidade humana à luz da Eucaristia aqui proposta seja justamente, sem ela. Ou melhor, através de outro rito que não o da Celebração Eucarística. Assim foi feito para, justamente, preservar a Eucaristia de seu sublime e mais digno lugar e condição na vida da Igreja. Foi para que não seja feito o que tem acontecido em vários lugares do mundo, banalizando a Eucaristia como se fosse possuidora de qualidades mágicas, através de práticas que desconsideram seu sentido e desrespeitam toda e qualquer norma do rito litúrgico.

Em vez disso, somos chamados a reafirmar e revalorizar a liturgia doméstica, cuja vida pode e deve ser alimentada através da oração dos mistérios de Cristo cantados nos Salmos, utilizando-se da força e sabedoria das Sagradas Escrituras. Esta é 
uma boa oportunidade para promover cada vez mais na Igreja a Oração das Horas, pascalizando por ela o cotidiano para ajudar a ler a realidade à luz da Eucaristia, Páscoa de Cristo Jesus, nosso Senhor e redentor.

\section{Referências Bibliográficas}

BÍBLIA SAGRADA. Tradução oficial da CNBB. Brasília: Ed. CNBB, 2018.

CNBB. As introduções gerais dos livros litúrgicos. São Paulo: Paulus, 2003. CONSTITUIÇÃO SACROSANCTUM CONCILIUM - sobre a Sagrada Liturgia In: Documentos do Concílio Ecumênico Vaticano II. São Paulo:

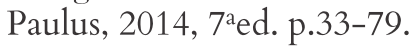

DECRETO INTER MIRIFICA - sobre os meios de comunicação social. In: Documentos do Concílio Ecumênico Vaticano II. São Paulo: Paulus, 2014, $7^{\mathrm{a} e d .}$. p.87-100.

SAGRADA CONGREGAÇÃO PARA O CULTO DIVINO. A Sagrada Comunhão e o Culto Eucarístico Fora da Missa. São Paulo: Paulus, 2000.

. Cerimonial dos Bispos. São Paulo: Paulus, 2001, $3^{\mathrm{a} e d .}$ . Liturgia das Horas. São Paulo: Paulinas, 1995. . Missal Romano. São Paulo: Paulinas, 1992, $2^{\mathrm{a} e d .}$ 